ANATOL JAKOBSON

Irkutsk State Railway University, Russia

\title{
A local crisis as a specific part of the global one: the case of Siberia
}

It is well known that our world has been surviving the global crisis. But, being geographers, we must think geographically. Any global phenomenon manifests itself differently in various countries and regions. When we speak about crisis in Russia, we understand that it simply must differ from that in any other country - that is in a country with other geographic position, with other dimensions of territory, with other climate, with other history, with other economic structure, with other population mentality and so on.

Moreover, the crisis in Siberia must differ from that in Moscow or in Northern Caucasus.

Our idea is that for Russia the global crisis can be considered as the third phase of the long-term national socio-economic crisis, and for the important part of Russia, Siberia, even as the fourth phase.

The crisis in Russia stems from the Soviet times. In its nature it was the crisis of economy, of ideology, of social relationships and of political system. This crisis was inherent to all so called socialist countries, but again, with some specificity in each case (for example, a good deal of Poland's specificity is connected with the fact that this country had saved - unlike the Soviet Union and other European countries of socialist block - private property in agriculture).

We are not going to discuss the question of the moment when this specific crisis started (the opinions among historians vary) but it is obvious that it did exist and that it brought the final crash of the state in 1991.

Political and economic reforms in Russian Federation have managed to solve some acute problems. First and most obvious was the one of consumer goods supply - after a long period of 'deficit', that is: lack of everything in the shops. Maybe the most important of the problems solved (we mention here only economic problems) was the emergence of the class of men and women ready for entrepreneurship and private business.

But some of the problems have not been solved yet, among them the one of technical backwardness of manufacturing industries and the policy of raw materials export orientation.

At the same time, a lot of new problems were just born by the reforms, and this gives us the right to speak about the second stage of the crisis in the 90s.

Among these new problems the most important, most difficult and, in fact, unsolvable one was, in our opinion, the very crush of the Soviet Union. Many authors as well as many common people living in Russia, in ex-Soviet republics or abroad (including Poland, as our 
personal discussions show) treat it as a Crush of the Empire (the title of a book written by a well known Russian liberal economist Yegor Gaidar, 2006), which stands in one row with the crushes of other empires of the 20th century, that is Austrian, Turkish, British and French.

That country had, of course, some features of a colonial empire: it was highly centralized, all the political and economic decisions were taken by a very narrow circle of people and, very important, the state, being the successor of the Russian Empire, tended to stay ethnocentric in its nature, which was manifested in personnel selection policy.

On the other hand, there are some facts that do not allow us to use this label, 'empire', when we speak about the Soviet Union and its crush.

Firstly, according to the Soviet Constitution, that state was a federation (unlike the Russian Empire, the memory of which is so familiar to Poland). The Republics, being formally the subjects of the Federation, were represented not only in official bodies but also in semi-formal or non-formal groups that, in the conditions of totalitarian state, used to perform the real power functions. At the same time, the ethnic cultures of 'title' peoples (such as Ukrainians, Georgians, Lithuanians, Uzbeks and others - that is having their 'own' republics, named for a corresponding ethnicity) did have satisfactory although slightly limited possibilities for development.

Secondly, unlike the empires mentioned, in the Soviet Union, there was no 'metropolitan' territory. Russia was not such a territory, the groups taking decisions did not and could not represent the interests of Russia as an entity.

Thirdly, there was the integral space of migration and settlement, of human contacts, there existed the integral multiethnic culture, although formed on the basis of Russian one, including literature, cinema, music - and at the same time there were such phenomena as cuisine and the integrated historical memory, including mutual memory about the Second World War (in the Soviet Union known as the Great Patriotic War) - and at the same time about victories in sports.

So, it is a good reason to speak in fact about an integral federal state, whose true analogue is not the British Empire but the United Kingdom of Great Britain (Russia in the role of England, Ukraine in the role of Scotland and so on). Another analogue is ex-Yugoslavia (Serbs in the role of Russians or English), having so much in common with the Soviet Union in its historical fate, although, obviously never having been an empire.

The principal difference is that Great Britain is a harmonically developing, wealthy and really democratic country, in which nationalists and separatists, although exist, have no real chances.

Certainly, the crush of the state was very painful for common people who even now do not recognize the new state with the new, shortened borders and with cut-off contacts as their Homeland.

Another problem was poverty, together with social pessimism and passiveness of many people who were robbed by the hyperinflation. Something like this was somehow present in other countries reforming their economies in market direction, including Poland. But the historic background in Russia was different. People there got used to paternalistic state economy after so many decades of its domination (much more than in Poland) together with strong paternalistic traditions in pre-revolutionary Russian monarchy. Many of those people could not even understand how they should behave in the new conditions of economic liberty and market competition. 
(This somehow contradicts to what was said about the emergence of the class of entrepreneurs. Certainly, this class does exist in today's Russia, and it has been a great success. But non-market thinking is even more typical).

A specific Russian problem was stagnation of the sectors, such as science and education, that had never been backward in the Soviet times. Soviet propaganda had tried sometimes to convince people that it was number one in the world. Of course, it was not true. But, being realistic, we can say now that in the 20th century the Soviet Union ranked among several most developed countries, in general after the USA, maybe after Great Britain, Germany or France. Those sectors could perhaps serve as the growth points for the new economy, if used and stimulated properly.

But those very sectors were neglected by those who performed the reforms. They leaned on ultra-liberal economic theories approved by the experience of reforms in some countries of Latin America. But they did not want to see the difference between those countries and Russia, seeing only common characteristics, crisis state of economy in the first turn. But Russia, unlike Latin America, was not an underdeveloped country at least in two aspects: first of them was respectively high level of living standards (such notions as starvation or homelessness had been already forgotten by the $60 \mathrm{~s}$ or $70 \mathrm{~s}$ ); the second aspect was just high level of literacy and education, the factor unknown to the reformers in Latin America.

This factor is connected with above mentioned technical backwardness and raw materials orientation. There is an opinion among liberal economists - of course, unpopular - that Russia has no other future but the fate of an underdeveloped country. Surely, such a position cannot make people enthusiastic.

Looking through the problems mentioned we can see an interesting and somehow paradoxical common feature: they are all not only of economic nature but to a great extent mental.

Such was the soil on which the signs of global crisis grew. While the rates of hyperinflation had slowly decreased and the Government began to speak about some normalization, Russia, already being involved in the global economic system, suffered the same difficulties as the whole world but here they were added to the national problems, still unsolved, and formed, in fact, in the third phase of one permanent crisis.

As some experts mark, an important problem is, again, Russian specificity of mentality of national businessmen. This aspect was investigated by Siberian economist Alexander Kolmakov [2009]. His principal conclusions are as follows.

Among those who formed Russian class of businessmen, rather typical was the group of people who worked in private business not to survive but to become rich. In the initial years of the market reforms such people often succeeded.

They were not psychologically prepared for any losses. And now, when the demand decreased, they do not want to take a reasonable decision: to reduce their prices in order to save their markets. Decreasing the prices seems impossible to them. Rather they prefer to decrease their activity.

Mental factors again!

When we speak about the third phase of the crisis, it seems a bit different for Siberia. Alongside with the second phase, Siberia has been surviving its own crisis.

To understand it we should recollect the idea of the "Siberian curse", put forward by American geographers Fiona Hill and Clifford Gaddy, whose book published in 2003 under this title has a subtitle: How communist planners left Russia out in the cold [Hill, Gaddy 2009]. 
According to this idea, Siberia is for Russia nothing but a burden, needed perhaps only to supply it with oil, gas and timber. Modern economic geography of this territory has been formed by 'communist planners' and is a big error in comparison with the picture that would have existed under conditions of free market economy. Now it must change and adopt itself to the new, reformed conditions. Regional policy, if needed at all, must be limited by helping people to leave this territory, without 'helping regions' that are inefficient.

The reasonable background of such ideas is the undisputable fact that, in the years of Stalin's rule, the development of some (some!) Siberian (as well as Far Eastern) regions had indeed a strange character. Such cities emerged in the Far North as Norilsk, Magadan, Vorkuta (the latter in European Russia) with population (nowadays) more than 100,000 inhabitants. Neither in Northern Canada or Alaska, nor in Scandinavian North can we find a settlement of comparable size which shows that their formation was an error.

The very word 'Siberia' is, for common people, usually associated with cold. In many European places (including Kraków) and America, had I an opportunity, introducing myself, to mention Siberia and to hear: oh, it must be very cold there!

Indeed, let us take one of the 'Soviet' Siberian cities, Norilsk, by now a significant center of copper, nickel, cobalt, platinum and other mining and extracting metals. The natural conditions are really severe and uncomfortable there - permafrost, long Polar nights, -40 to $-50^{\circ} \mathrm{C}$ in winter, cold winds, snowfalls, etc. Most people who built the city the mines and the plants had come here unwillingly and a lot of them found their death here.

To support life of such monstrous cities in more liberal but still socialist times, it was necessary to give people living there numerous benefits. This was not, of course, efficient from economic point of view and was not good for inhabitants' health, or, speaking in today's terms, for the quality of life.

This is what American authors criticize. This is what they call 'living out in the cold'. But no difference is noticed by them between Northern regions uncomfortable for human life, Southern Siberia where Russian people have been living for centuries and the areas inhabited by native Siberian peoples.

For example, Irkutsk, in Southern Siberia, was founded in the 17th century and by 1917 had as many as nearly 100,000 inhabitants. Certainly, the climate here is not as comfortable as in Crimea or Italy, but still quite satisfactory. As well as in Omsk, Novosibirsk, Krasnoyarsk and other cities along Transsiberian railroad. Out-migration from these places exists but most of their inhabitants prefer to live just there, where they have job and homes.

It can be added that (I have written about it in details in the work [Jacobson, 2010]) Irkutsk is situated in the area where Buryats, native Siberian people live and did live before the Russian came along. They live in rural as well as urban settlements, their way of living (peasants, workers, intellectuals, businessmen, office clerks, etc.) does not differ greatly from that of Europeans (although their agriculture by now deals with cattle breeding much more than with growing vegetables). Certainly Buryats do not need to be helped to live.

But why so much attention is being paid to just one book of some American authors? We know that their ideas were adopted by some Russian experts living in Moscow. We know this from private discussions, even from reports at some conferences, but such experts try not to express this in their publications.

These ideas go alongside with two others, paradoxically contradictory to each other and at the same time coinciding. One of them is ultra-liberalism in economic policy, and it is clear that such economists like the anti-planning, anti-socialist ideas of Hill and Gaddy. 
The other is hyper-centralization in today's Russia, the tendency even stronger than it used to be in the Soviet Union. This tendency goes simultaneously from authoritarian Government and from the market processes that, going without any State regulation, lead automatically to concentration of everything in wealthy Moscow.

Such ideas influence economic policy which results for Siberia in extensive outmigration and depopulation.

This is the situation in which Siberia is meeting the global crisis.

\section{References}

Gaidar, Ye., 2006, Gibel imperii. Moscva: ROSSPAN.

Kolmakov, A.Ye., 2009, The specific features of Russian people behavior in the crisis economy. [in:] Road, Region, Market. Irkutsk: Irkutsk State Railroad University, pp. 57-63.

Hill, F., Gaddy, C.G.. 2003, The Siberian Curse. How Communist Planners Left Russia Out in the Cold. Washington, DC: Brooking Institution Press.

Jakobson, A., 2010, Evolution of the city of Irkutsk economic-geographic position in various scales. [in:] Procesy przemian przemysłu i usług w wybranych krajach. Warszawa-Kraków, pp. 9-19.

\section{A local crisis as a specific part of the global one: the case of Siberia}

Any global phenomenon manifests itself differently in various countries and regions. Our idea is that for Russia the global crisis can be considered as the third phase of the long-term national socio-economic crisis, and for the important part of Russia, Siberia, even as the fourth phase.

These phases are:

- First, the crisis of economy, of ideology, of social relationships and of political system stemming from the Soviet times, having brought the crush of the state, some problems of which have been still unsolved;

- Second, the crisis of the $90 \mathrm{~s}$, born from this crash and economic reforms, including the very crush of the integral country, very painful for common people, poverty, together with social pessimism and passiveness of people who were robbed by the hyperinflation and stagnation of the sectors, such as science and education, that had never been backward in the Soviet times and could perhaps serve as growth points for the new economy, if used and stimulated properly.

- Third, specifically Siberian, extensive out-migration and depopulation, in the conditions when state economic policy is influenced by ultra-liberalism denying any state regulation, together with power hyper-centralization, which both tendencies, paradoxically united, lead automatically to concentration of everything in wealthy Moscow.

- Fourth, the very global crisis itself.

Prof. Anatol Jakobson, doctor of geographic sciences

Irkutsk State Railway University, Russia

e-mail: yakobson_ay@irgups.ru 